\title{
Characterization of Coagulase-Negative Staphylococci and pheno-genotypic beta lactam resistance evaluation in samples from bovine Intramammary infection
}

\author{
[Caracterização de Staphylococcus coagulase negativa e avaliação fenogenotípica da resistência \\ aos beta-lactâmicos em amostras oriundas de infecção intra-mamária em bovinos] \\ D.A. Melo, C.C. Motta, A.C.C. M. Rojas, B.S. Soares, I.S. Coelho, \\ S.M.O. Coelho, M.M.S. Souza \\ Universidade Federal Rural do Rio de Janeiro - Seropédica, RJ
}

\begin{abstract}
This study aimed to identify Coagulase-Negative Staphylococci (CoNS) species isolated from bovine mastitis, through phenotypic and PCR-RFLP (Restriction Fragment Length Polymorphism-Polimerase Chain Reaction) methods and to compare both techniques to matrix-assisted laser desorption/ionization time-of-flight mass spectrometry (MALDI-TOF MS) technique. Among them, the PCR-RFLP method, using a partially conserved sequence of the groEL gene, is a promising alternative, because of its reproducibility and reliability. On the other hand, the proteomic technique MALDI-TOF MS provides an accurate and much faster diagnosis and has been increasingly employed in microbiological identification. The pheno-genotypic profiles of beta-lactam resistance were also investigated, this characterization is important, considering that the use of antimicrobials is a key element for mastitis control in dairy farms. The concordance of the phenotypic, PCR-RFLP and MALDI-TOF MS assays to identify CoNS species was $77,5 \%$ (31/40). S. chromogenes was the species most frequently isolated. Antibiotic resistance rate was relatively low, registering values of $25.5 \%$ to penicillin, $9.6 \%$ to oxacillin and $6.2 \%$ to cefoxitin. Resistance to imipenem, cephalotin and amoxicillin+clavulanate was not observed. The mecA gene and its variant were detected in $7.6 \%$ and $4,1 \%$ of the isolates respectively. The blaZ gene was found in $43.2 \%$ of the strains resistant to penicillin.
\end{abstract}

Keywords: Staphylococcus spp., bacterial resistance, PCR-RFLP and MALDI-TOF MS

\section{RESUMO}

Este estudo teve como objetivo identificar isolados de Staphylococcus coagulase-negativa (SCN) isolados de mastite bovina, por meio de métodos fenotípicos e PCR-RFLP (reação em cadeia de polimerase - polimorfismo nos fragmentos de restrição), e compará-los com a técnica de tempo de voo de ionização/desorção por laser assistida por matriz de espectrofotometria de massa (MALDI-TOF MS). O método de PCR-RFLP, que utiliza uma parte conservada da sequência do gene groEL, é uma alternativa promissora, por ser reprodutível e confiável. Por outro lado, a técnica proteômica MALDI-TOF MS permite uma acurácia e um diagnóstico muito mais rápidos e tem sido cada vez mais empregada na identificação microbiológica. Os perfis fenogenotípicos de resistência aos beta-lactâmicos também foram investigados. Essa caracterização é importante, considerando-se que os antimicrobianos são os elementos-chave para o controle da mastite na produção leiteira. A concordância entre os testes fenotípicos, PCR-RFLP E MALDI-TOF MS na identificação foi de 77,5\% (31/40). S. chromogenes foi a espécie mais frequentemente isolada. A resistência antimicrobiana foi relativamente baixa, apresentando valores de 25,5\% para penicilina, 9,6\% para oxacilina e 6,2\% para cefoxitina. Resistência ao imipenem, à cefalotina e à amoxacilina + ácido clavulâncico não foi observada. $O$ gene mecA e sua variante foram detectados em 7,6\% e 4,1\% dos isolados, respectivamente. O gene bla $\mathrm{Z}$ foi encontrado em $43,2 \%$ dos isolados resistentes à penicilina.

Palavras-chave: Staphylococcus spp., resistência bacteriana, PCR-RFLP, MALDI-TOF espectrofotometria de massa

Recebido em 31 de maio de 2016

Aceito em 3 de fevereiro de 2017

E-mail: daymelo.com@gmail.com 


\section{INTRODUCTION}

Coagulase negative staphylococci (CoNS) are a heterogeneous group of species with limited but significant impact on dairy farms (Zadoks et al., 2011). At least 15 species have been associated with bovine mastitis, but Staphylococcus chromogenes, S. epidermidis, S. xylosus and S. haemolyticus are reported as the most prevalent species in herds around the world (Piessens et al., 2012; Frey et al., 2013). While S. chromogenes rarely occurs in humans, $S$. epidermidis commensally inhabits the human skin and mucous membranes. Strains of $S$. epidermidis from bovine intramammary infections (IMIs) frequently exhibit multidrug resistance and there is evidence of its transmission through milkers's hands to the bovine udders (Sawant et al., 2009; Sampimon et al., 2011). Several molecular approaches have been suggested for the proper identification of CoNS, since phenotypic methods are timeconsuming and unreliable for animal samples (Park et al., 2011). PCR-RFLP of the groEL or hsp60 (heat-shock protein) gene has been effectively employed in the identification of CoNS from both bovine and caprine mastitis (Santos et al., 2008; Onni et al., 2012). Recently, the proteomic method MALDI-TOF MS has been increasingly used in microbial identification, due to its reliability, speed, and ease of use. MALDI-TOF MS produces a characteristic spectrum of the analyzed microorganisms, allowing accurate identification and classification of bacterial strains. This method was successfully applied to identify CoNS isolates from clinical and environmental samples (Dubois et al., 2010). Lack of susceptibility to penicillin and other beta-lactams is frequently found among CoNS isolated from cattle (Sampimon et al., 2011). This resistance is usually caused by the constitutive or induced production of a penicillinase, coded by the bla $\mathrm{Z}$ gene. Alternatively, it can result from the expression of the mecA gene, which encodes PBP2a, a modified PBP (penicillin binding protein) and gives resistance to all beta-lactams, including carbapenems, monobactams and cephalosporins. The aims of this study were to compare the prevalence and antimicrobial susceptibility of CoNS species in bovine mastitis, identified by phenotypical tests, PCRRFLP and MALDI-TOF MS, and to determine the prevalence of mec $\mathrm{A}$ and bla $\mathrm{Z}$ genes in these strains.

\section{MATERIALS AND METHODS}

The California Mastitis Test was performed on 680 lactating cows from nine dairy herds, in the Brazilian state of Rio de Janeiro. Positive animals had individual mammary quarter milk samples $(10 \mathrm{~mL})$ aseptically collected into sterile vials immediately before milking, after discarding the first three milking streams. The 512 milk samples obtained were transported to the laboratory and directly cultured $(10 \mu \mathrm{L})$ on $5 \%$ sheep blood agar and mannitol salt phenol red agar plates. The agar plates were incubated at $37^{\circ} \mathrm{C}$ for $24 \mathrm{~h}$. Ethics committee, (protocol number, CEUA3664040915), certified this research.

A modified scheme based on Cunha et al. (2004) was used to identify CoNS isolates, comprising the following tests: fermentation of the sugars xylose, arabinose, sucrose, trehalose, maltose, mannitol, lactose, xylitol, ribose, fructose and mannose; production of hemolysin; presence of urease; and resistance to novobiocin $5 \mathrm{mcg}$ (Cefar). Standards strains were used as control. The following type strains were included in the study: S. simulans ATCC $27851^{\mathrm{T}}$, S. warneri ATCC $10209^{\mathrm{T}}$, S. saprophyticus ATCC15305 ${ }^{\mathrm{T}}$, S. epidermidis ATCC $12228^{\mathrm{T}}$, S. hominis ATCC $27844^{\mathrm{T}}$, S. xylosus ATCC $29971^{\mathrm{T}}$, S. aureus ATCC $43300^{\mathrm{T}}$ and S. aureus ATCC $29213^{\mathrm{T}}$. In addition, three clinical strains, all identified by the conventional biochemical method, were used as positive control strains of $S$. sciuri, $S$. chromogenes and $S$. hyicus. All strains were grown overnight on mannitol salt phenol red agar plates at $37^{\circ} \mathrm{C}$ for examination of purity and colony characteristics.

To genomic DNA extraction, the isolates were grown in $5 \mathrm{~mL}$ of nutrient broth at room temperature for $12-16 \mathrm{~h}$ with stirring at $150 \mathrm{rpm}$. A $1.5 \mathrm{~mL}$ aliquot was pelleted by centrifugation at $12000 \mathrm{rpm}$ for $5 \mathrm{~min}$. The supernatant was discarded and this step was repeated twice. The pellets were resuspended in $600 \mu \mathrm{L}$ of a lysis buffer $(200 \mathrm{mM}$ Tris- $\mathrm{HCl} \mathrm{pH}$ 8.0, 25mM EDTA $\mathrm{pH} 8.0,25 \mathrm{mM} \mathrm{NaCl}, 1 \% \mathrm{SDS}$ ) followed by incubation at $65^{\circ} \mathrm{C}$ for $30 \mathrm{~min}$. The aqueous phase was extracted twice with chloroform/isoamyl alcohol (24:1), at $13000 \mathrm{rpm}$ for $10 \mathrm{~min}$. The 
DNA was precipitated with two volumes of $100 \%$ ethanol, at $-20^{\circ} \mathrm{C}$ for $12 \mathrm{~h}$. Microtubes were centrifuged at 13000 for $30 \mathrm{~min}$ and the resulting pellets were washed with $70 \%$ ethanol, dried and resuspended in $30 \mu \mathrm{L}$ TE buffer $(10 \mathrm{mM}$ Tris$\mathrm{HCl}, 1 \mathrm{mM}$ EDTA, $\mathrm{pH}$ 8.0).

PCR amplification of the groEL gene and PCRRFLP assay were performed by groEL degenerate primers H279A (5'GAIIIIGCIGGIGA(TC)GGIACIACI AC-3') and H280A (5'-(TC)(TG)I(TC)(TG)ITCICC(AG) AAICCIGGIGC(TC)TT-3'), previously described (Goh et al., 1997), were used to amplify a 550-bp groEL gene fragment as described by Santos et al. (2008). To exclude cross-profile with other CoNS, a computational restriction fragment analysis was performed using all staphylococci hsp60 sequences stored in the GenBank and the program NEBCutter v2.0 (http://tools.neb.com/ NEBcutter2/).

Forty isolates randomly chosen and the 21 which could not be identified by PCR-RFLP were identified at the species level by MALDI-TOF MS. Pure cultures were grown on BHI agar at $37^{\circ} \mathrm{C}$ for $24 \mathrm{~h}$. A small amount from a colony of each pure culture was transferred to a 96-spot target well (96 MSP, Bruker - Billerica, EUA) using a disposable loop, added to $70 \%$ formic acid lysis solution (Sigma-Aldrich), and overlaid with $1 \mu \mathrm{L}$ of matrix ( $\alpha$-cyano-4-hydroxycinnamic acid diluted with $50 \%$ acetonitrile/2.5\% trifluoroacetic acid, Sigma-Aldrich). All samples were processed in positive linear mode $(\mathrm{m} / \mathrm{z}=$ 2000-20,000), with a 337nm nitrogen laser (FlexControl 3.3 software, Bruker). Each spectrum was analyzed and considered valid when the score matched those of reference spectra of the MALDI Biotyper v2.0 database (Bruker Daltonics $\mathrm{GmbH}$ ) and was $\geq 2$, according to the criteria proposed by the manufacturer.

All isolates were tested for beta-lactam susceptibility by disk diffusion test (Performance..., 2013a,b). The following antimicrobial disks were used: penicillin G (10UI), cefoxitin $(30 \mu \mathrm{g})$, oxacillin $(1 \mu \mathrm{g})$, amoxicillin+clavulanate $(30 \mu \mathrm{g}), \quad$ cephalothin $(30 \mu \mathrm{g})$ and imipenem $(10 \mu \mathrm{g})$.

Genotypic resistance profiles were determined by PCR, targeting genes encoding resistance to beta-lactams, including mec genes: mecA (Murakami et al., 1991), mecA variant (Melo et al., 2014), and mecA1 (pbpD) (Couto et al., 2010); mecI (Lencastre et al., 2002), mecRI (Rosato et al., 2003), and blaZ (Rosato et al., 2003).

\section{RESULTS}

The isolates were identified using different techniques: phenotypical tests, PCR-RFLP (Figure 1A), and MALDI- TOF MS) (Table 1). Twenty-one isolates were unable to amplify the $550 \mathrm{bp}$ fragment of the groEL gene, and could not be identified by this technique. Two different patterns were observed for $S$. chromogenes strains, resulting from an intraspecific polymorphism. Sixty-eight isolates identified as $S$. chromogenes showed the characteristic RFLP pattern for this specie, while 16 isolates exhibited an atypical pattern, with only two fragments. Apparently, a restriction site for AluI was lost, and the 75bp and 107bp fragments resulted in a single fragment of approximately 200bp (Figure 1B). Double digestion has been suggested for isolates classified as $S$. chromogenes, to better differentiate this specie from $S$. hyicus and $S$. capitis (Santos et al., 2008). The 84 strains, presumptively classified as $S$. chromogenes, were subjected to PvuII/HindIII endonucleases. All of them showed the same pattern (Figure 1C), confirming the initial identification and indicating that the restriction sites for PvuII/HindIII were not affected by the intraspecific variability.

In total, $95 \%$ of the 61 isolates were clearly identified at the species level by MALDI-TOF MS analysis (Table 1). Three isolates ( $S$. auricularis and $2 S$. hyicus) had scores between 1.8 and 2.0, meaning the genus identification was considered secure but the identification was only probable at the species level.

The species identification of the 40 strains previously identified by the PCR-RFLP method was confirmed by the MALDI-TOF analysis, showing $100 \%$ concordance. The concordance of the phenotypic, PCR-RFLP and MALDI-TOF MS assays to identify CoNS species was $77,5 \%$ (31/40). The 21 isolates which failed to amplify the partial fragment of groEL were also identified by proteomics as CoNS strains. $S$. chromogenes was the most prevalent species (70\%). 
Table 1. Frequency of distribution of coagulase-negative staphylococci identified by Phenotypic test, PCR-RFLP and MALDI-TOF MS

\begin{tabular}{cccc}
\hline CoNS species & Phenotypical Identification & \multicolumn{2}{c}{ Molecular Identification } \\
& & PCR-RFLP & MALDI- TOF MS \\
\hline S. chromogenes & $63.4 \%(92)$ & $57.9 \%(84)$ & $70.5 \%(43)$ \\
S. sicuri & $6.9 \%(10)$ & $6.9 \%(10)$ & $2.5 \%(4)$ \\
s. xylosus & $5.5 \%(8)$ & $6.9 \%(10)$ & $3.3 \%(2)$ \\
S. lugdunensis & $4.8 \%(7)$ & $1.4 \%(2)$ & $1.6 \%(1)$ \\
S. simulans & $3.4 \%(5)$ & $1.4 \%(2)$ & $1.6 \%(1)$ \\
S. hyicus & $3.4 \%(5)$ & - & $3.3 \%(2)$ \\
S. auriculares & $3.4 \%(5)$ & - & $1.6 \%(1)$ \\
S. warneri & $2.75 \%(4)$ & $3.4 \%(5)$ & $4.9 \%(3)$ \\
S. epidermidis & $2.1 \%(3)$ & $2.75 \%(4)$ & $3.3 \%(2)$ \\
S. haemolyticus & $1.4 \%(2)$ & $1.4 \%(2)$ & - \\
S. hominis & $1.4 \%(2)$ & $2.1 \%(3)$ & $3.3 \%(2)$ \\
S. cohnii & $0.7 \%(1)$ & $1.4 \%(2)$ & - \\
S. schleiferi subsp. Schleiferi & $0.7 \%(1)$ & - & - \\
Not identified & - & $14.5 \%(21 / 145)$ & - \\
Total & 145 & 124 & 61 \\
\hline
\end{tabular}
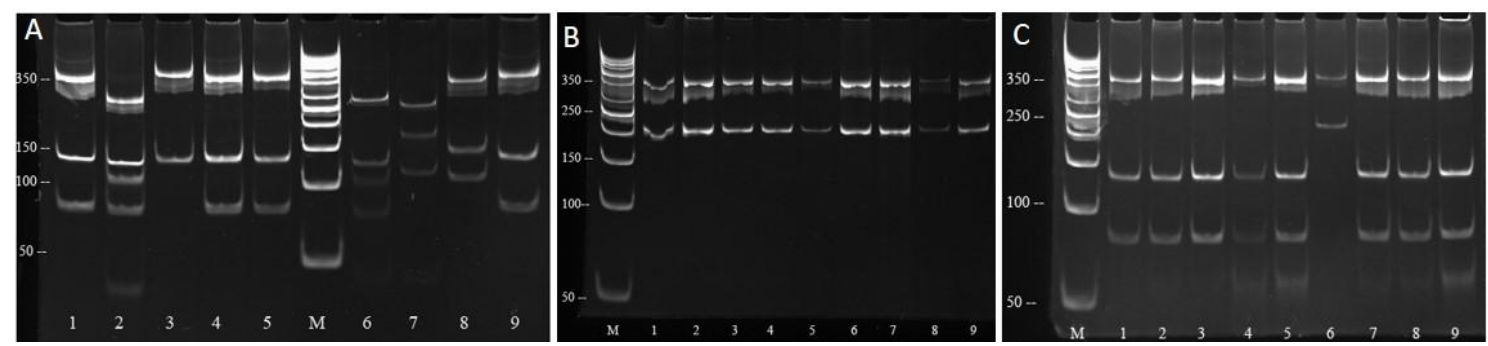

Figure 1. Genotypic identification by PCR-RFLP of the groEL gene. A: (1), (4) e (5) S. chromogenes strains; (2) S. xylosus strain; (3) S. haemolyticus strain; (6) S. xylosus ATCC 29971 ${ }^{\mathrm{T}}$, (7) S. simulans ATCC $27851^{\mathrm{T}}$, (8) S. warneri ATCC $10209^{\mathrm{T}}$ and (9) S. chromogenes control strain, (M) 50bp ladder. B: (1-8) S. chromogenes isolates; (6) S. chromogenes isolate showing an atypical pattern for the species with only two fragments; (9) S. chromogenes control strain, (M) 50bp ladder. C: (1-8) S. chromogenes isolates after double digestion with HindIII/PvuII; isolates 5, 6, 7 and 8 had shown an anomalous pattern after digestion with AluI; (9) S. chromogenes control strain, (M) 50bp ladder.

The biochemical tests showed a concordance of $78.6 \%$ with the final identification. Species such as $S$. chromogenes, S. xylosus and S. sciuri showed a better concordance coefficient, around $90 \%$, but speciation was particularly problematic for S. simulans and S. lugdunensis.

The genotypic technique showed sensitivity of $85.5 \%$, a consequence of 21 isolates failing to produce amplicons with the primers and PCR conditions used. These could only be identified by proteomics.

Resistance to cefoxitin was found in $6.2 \%$ of isolates (9/145). As expected, these strains were also resistant to the other beta-lactams tested. They were identified as $S$. chromogenes (3), $S$. epidermidis (3), S. hominis (2) and S. hyicus (1), but only $2 S$. epidermidis were positive for the $m e c \mathrm{~A}$ and $m e c \mathrm{RI}$ genes. Another 9 isolates, $6 \mathrm{~S}$. sciuri and 3 S. chromogenes, were also positive for the mecA gene (Murakami et al., 1991) and other $6 \mathrm{~S}$. sciuri were positives for the mecA variant (Melo et al., 2014), but they were susceptible to all antimicrobials. They were also negative for the mecI and mecRI genes.

Fourteen isolates were resistant to oxacillin, but five of them were susceptible to cefoxitin, indicating a resistance mechanism by betalactamase hyperproduction. Resistance to penicillin was encountered in $25.5 \%$ isolates (37/145) but only $43.2 \%$ of them (16/37) were positive for the blaZ gene, most of which were 
identified as $S$. chromogenes (13/16). This gene was also found in one isolate each of $S$. sciuri, $S$. epidermidis and S. auricularis.

The mecA analog ( $p b p \mathrm{D})$ was found in $19.3 \%$ of the CoNS isolates $(28 / 145)$. This gene was detected in $40 \%$ of $S$. sciuri (4/10), $100 \%$ of $S$. warneri (6/6), $14 \%$ of $S$. chromogenes (14/101) and in one isolate each of $S$. xylosus, $S$. lugdunensis, S. hominis and S. cohnii. Except for the nine methicillin-resistant CoNS, resistance to cephalotin, imipenem and amoxicillin+clavulanate was not observed.

\section{DISCUSSION}

The increasing number of CoNS species and the high frequency in bovine IMIs with which these microorganisms makes diagnosis a challenge (Thorberg et al., 2009). The conventional method of identification, based on laborious biochemical schemes, remained a hindrance to further understanding of their real impact on dairy farms, several molecular techniques were developed in an attempt to assist in CoNS speciation, such as sequencing of housekeeping genes, ribotyping and AFLP fingerprinting, among others (Park et al., 2011). These tools helped to clarify to some degree which species were prevalent in bovine mastitis and what kind of resistance profiles they possessed. $S$. chromogenes, S. simulans, S. xylosus and $S$. epidermidis are usually reported as the most isolated species. S. epidermidis is frequently associated with multidrug resistance (Sampimon et al., 2011; Waller et al., 2011; Frey et al., 2013). Among the several genotypic methods suggested for correct CoNS identification, PCRRFLP of the groEL gene is a reliable option, with good reproducibility. In this study, we used this technique to identify $145 \mathrm{CoNS}$ strains. When it was first proposed by Barros et al. (2007), polymorphisms in S. aureus and S. lugdunensis were observed, and this kind of occurrence was not ruled out for other species. Likewise, we detected an intraspecific polymorphism in S. chromogenes. Mutations in a restriction site of AluI are the likely cause of the anomalous RFLP pattern. This, however, did not reduce the discriminatory power of the method, as the atypical pattern observed for $S$. chromogenes was not similar to any of the other CoNS. Moreover, the double digestion with PvuII/HindIII suggested for $S$. chromogenes strains confirmed the initial identification. Out of 145 isolates, $124(85.5 \%)$ were accurately speciated by PCR-RFLP. The remaining 21 strains did not produce amplicons, preventing characterization by this method. These strains and another 40 were identified by MALDI-TOF MS. The 21 isolates belonged to the following species: S. chromogenes (17/21), S. hyicus $(2 / 21), S$. warneri (1/21) and $S$. auricularis $(1 / 21)$. The 40 randomly chosen isolates had their identification by the PCR-RFLP of the groEL confirmed by the MALDI-TOF MS. This proteomic method is being increasingly employed in microbiology research, since it is a powerful tool for species identification. The high prevalence of $S$. chromogenes found in this study is in accordance with the observation that this specie, along with $S$. simulans, $S$. epidermidis and $S$. xylosus, is the most prevalent CoNS found in bovine mastitis (Sawant et al., 2009; Piessens et al., 2012). Still, S. epidermidis multidrug resistance is frequently reported, suggesting it is a more problematic pathogen. The fact that humans naturally harbor this microorganism also implies a zooanthroponotic potential (Sampimon et al., 2011). Concerning the resistance profiling, according to the CLSI guidelines, the disk diffusion test using cefoxitin is the preferred method for the evaluation of PBP2a production in CoNS isolated from animals. Except for $S$. epidermidis, oxacillin interpretative criteria usually overestimate methicillin resistance for other CoNS. Nonetheless, the most accurate prediction of resistance against beta-lactams, including penicillinase-stable penicillins, include the detection of the mecA gene through PCR or screening for $\mathrm{PBP} 2 \mathrm{a}$ production, using latex agglutination tests. Lack of susceptibility to antibiotics commonly used in bovine mastitis is reportedly low. Penicillin resistance is the most prevalent and many articles report values around $15 \%$ to $30 \%$ (Piessens, 2011; Saini et al., 2012; Frey et al., 2013). Resistance against cefoxitin usually ranges from $2 \%$ to $10 \%$ in CoNS (Sawant et al., 2009; Fessler et al., 2010; Waller et al., 2011; Sampimon et al., 2011; Frey et al., 2013). In this study, a similar trend was observed with penicillin and cefoxitin resistance reaching values of $25.5 \%$ and $6.2 \%$, respectively. Detection of resistance genes did not correlate well with the phenotypic results. Even though the mecA gene was found in 11 strains, only two of them showed resistance to cefoxitin. The mecA variant typical from bovine samples, impossible 
to detected by routine PCR (Melo et al., 2014), was found in $6 \mathrm{~S}$. sciuri, that were all susceptible to cefoxitin too. Kim et al. (2013) made a study explaining the hetero-resistance to the betalactam family of antibiotics in methicillin resistant isolates. Inversely, seven isolates which were resistant in the cefoxitin disk diffusion test were negative for the mecA genes, another mechanism could be responsible for this resistance, Garcia-Alvarez et al. (2011) described a new homolog of mecA, called mec $\mathrm{C}$, this gene has been detected in humans and animals, but until the present date it was not found in the Americas.

The blaZ gene was found in $43.2 \%$ (16/37) of the isolates resistant to penicillin and most of them (13/16) were identified as $S$. chromogenes. Multiresistance was found in three, out of four $S$. epidermidis, and two of them harbored mec $\mathrm{A}$ and $m e c \mathrm{RI}$ genes. The mec $\mathrm{A} 1$ analog $(p b p \mathrm{D})$ was found in $40 \%$ of $S$. sciuri and in other CoNS, such as $S$. warneri and $S$. chromogenes. Although it has been postulated that this gene is the evolutionary precursor of the mecA in $S$. aureus, its role as a resistance determinant has not been established (Couto et al., 2010; Tsubakishita et al., 2010). We did not find any correlation between the presence of mecA1 and beta-lactam resistance.

\section{CONCLUSION}

MALDI-TOF MS is the best alternative method for CoNS species identification from samples isolated from dairy cows with IMIs, and $S$. chromogenes is the most frequently isolated microorganism. Whereas the poor correlation between phenotypic and genotypic characterization of antimicrobial resistance support the hypothesized that these isolates have higher degrees of variability or may suffer mutations that prevent detection. New mechanisms need to be investigated, to better understand this kind of resistance.

\section{REFERENCES}

BARROS, E.M.; IORIO, N.L.; BASTOS, M.F.B. et al. Species-level identification of clinical staphylococcal isolates based on polymerase chain reaction-restriction fragment length polymorphism analysis of a partial groEL gene sequence. Diagn. Microbiol. Infect. Dis., v.59, p.157-251, 2007.
COUTO, I.; LENCASTRE, H.; SEVERINA, E. et al. Ubiquitous presence of a mec A homologue in natural isolates of Staphylococcus sciuri. Microb. Drug Resist. v.2, p.377-391, 2010

CUNHA, M.L.R.S.; SINZATO, Y.K.; SILVEIRA, L.V.A. Comparison of methods for the identification of coagulase-negative staphylococci. Mem. Inst. Oswaldo Cruz., v.99, p.855-860, 2004.

DUBOIS, D.; LEYSSENE, D.; CHACORNAC, J.P. et al. Identification of a variety of Staphylococcus species by matrix-assisted laser desorption ionizationtime of flight mass spectrometry. J. Clin. Microbiol., v.48, p.941-945, 2010.

FESSLER, A.T.; BILLERBECK, C.; KADLEC, K.; SCHWARZ, S. Identification and characterization of methicillin-resistant coagulase-negative staphylococci from bovine mastitis. J. Antimicrob. Chemother. v.65, p.1576-1582, 2010.

FREY, Y.; RODRIGUEZ, J.P.; THOMANN, A. et al. Genetic characterization of antimicrobial resistance in coagulase-negative staphylococci from bovine mastitis milk. J. Dairy Sci., v.96, p.2247-2257, 2013.

GARCÍA-ÁLVAREZ， L.; HOLDEN， M.T.; LINDSAY, H. et al. Meticillin-resistant Staphylococcus aureus with a novel mecA homologue in human and bovine populations in the UK and Denmark: a descriptive study. Lancet Infect. Dis., v.11, p.595-603, 2011.

GOH, S.H.; SANTUCCI, Z.; KLOOS, W.E. et al. Identification of Staphylococcus species and subspecies by the chaperonin 60 gene identification methods and reverse checkerboard hybridization. $J$. Clin. Microbiol. v.35, p.3116-3121, 1997.

KIM, C.; MWANGI, M.; CHUNG, M. et al. The mechanism of heterogeneous beta-lactam resistance in MRSA: key role of the stringent stress response. Plos One, v.8, p.1-10, 2013.

LENCASTRE, H.; OLIVEIRA, D. C. Multiplex PCR strategy for rapid identification of structural types and variants of the mec element in methicillin-resistant Staphylococcus aureus. Antimicrob. Agents Chemother. v.46, p.2155-2161, 2002.

MELO, D.A.; COELHO, I.S.; MOTTA, C. C. et al. Impairments of mecA gene detection in bovine Staphylococcus spp. Braz. J. Microbiol. v.45, p.10751082, 2014

MURAKAMI, K.W.; MINAMIDE, K.; WADA, W. et al. Identification of methicillin resistant strains of staphylococci by polymerase chain reaction. J. Clin. Microbiol. v.29, p.2240-2244, 1991. 
ONNI, T.; VIDILI, A.; BANDINO, E. et al. Identification of coagulase-negative staphylococci isolated from caprine milk samples by PCR-RFLP of groEL gene. Small Ruminant Res., v.104, p.185-190, 2012.

PARK, J.Y.; FOX, L.K.; SEO, K.S. et al. Comparison of phenotypic and genotypic methods for the species identification of coagulase-negative staphylococcal isolates from bovine intramammary infections. Vet. Microbiol., v.147, p.142-148, 2011.

PERFORMANCE standards for antimicrobial disk and dilution susceptibility tests for bacteria isolated from animals. VET01-A4. Approved Standard. 4.ed. Wayne, PA: CLSI, 2013a.

PERFORMANCE standards for antimicrobial disk and dilution susceptibility tests for bacteria isolated from animals. VET01-S2. Wayne, PA: CLSI, Suppl.2. 2013b.

PIESSENS, V. Epidemiology and characterization of coagulase-negative Staphylococcus species from dairy farms. 2011. 213f. Tese (Doutorado em Ciências Veterinárias) - Faculty of Veterinary Medicine, Ghent University, BEL.

PIESSENS, V.; DE VLIEGHER, S.; VERBIST, B. et al. Intra-species diversity and epidemiology varies among coagulase-negative Staphylococcus species causing bovine intramammary infections. Vet. Microbiol. v.155, p.62-71, 2012.

ROSATO A.E.; KREISWIRTH B.N.; GRAIG W.A. et al. mecA-blaZ corepressors in clinical Staphylococcus aureus isolates. Antimicrob. Agents Chemother., v.47, p.1463-1466, 2003.

SAINI, V.; MCCLURE, J.T.; LÉGER, D. et al Antimicrobial resistance profiles of common mastitis pathogens on Canadian dairy farms. J. Dairy Sci., v.95, p.4319-4332, 2012.
SAMPIMON, O.C.; LAM, T.J.; MEVIUS, D.J. et al. Antimicrobial susceptibility of coagulase-negative staphylococci isolated from bovine milk samples. Vet. Microbiol., v.150, p.173-179, 2011.

SANTOS, O.C.; BARROS, E.M.; BRITO, M.A. et al. Identification of coagulase-negative staphylococci from bovine mastitis using RFLP-PCR of the groEL gene. Vet. Microbiol., v.130, p.134-140, 2008.

SAWANT, A.A.; GILLESPIE, B.E.; OLIVER, S.P. Antimicrobial susceptibility of coagulase-negative Staphylococcus species isolated from bovine milk. Vet. Microbiol., v.134, p.73-81, 2009.

THORBERG, B.M.; DANIELSSON-THAM, M.L.; EMANUELSON, U. et al. Bovine subclinical mastitis caused by different types of coagulase negative staphylococci. J. Dairy Sci., v.92, p.4962-4970, 2009.

TSUBAKISHITA, S.; KUWAHARA-ARAI, K.; SASAKI, T.; HIRAMATSU, K. Origin and molecular evolution of the determinant of methicillin resistance in staphylococci. Antimicrob. Agents Chemother. v.54, p.4352-4359, 2010.

WALLER, K.P.; ASPAN, A.; NYMAN, A. et al. CNS species and antimicrobial resistance in clinical and subclinical bovine mastitis. Vet. Microbiol. v.152, p.112-116, 2011.

ZADOKS, R.N.; MIDDLETON, J.R.; MCDOUGALL, S. et al. Molecular epidemiology of mastitis pathogens of dairy cattle and comparative relevance to humans. J. Mamm. Gland Biol. Neoplasia, v.16, p.357-372, 2011. 